\title{
The sustainable energy approach in the manufacture of cellular concrete
}

\author{
Ruben Kazaryan ${ }^{1, *}$, and Konstantin Belyaev ${ }^{1}$ \\ ${ }^{1}$ Moscow State University of Civil Engineering, Yaroslavskoe shosse, 26, Moscow, 129337, Russia
}

\begin{abstract}
Cellular concrete holds one of the leading places in world practice of construction as a structural heat insulating material used in the construction and reconstruction of buildings and structures for various purposes. Excessive (reserve) porosity of cellular concrete provides its frost resistance (compensates expansion of water when freezing and the formed ice without destroying the material). Vapor permeability of cellular concrete provides fast removal of technological moisture from the material and the maintenance of normal moisture conditions in the rooms, and rather high air permeability contributes to the preservation of fresh air in the rooms. Thermal insulation and strength properties of cellular concrete allow erecting single-layer enclosing structures with the required thermal resistance from it. Cellular concretes are divided into aerated concrete and foam concrete, the operating, physical and mechanical parameters of which are almost the same with all other things being equal. According to the hydrothermal treatment method, cellular concrete is divided into two groups: autoclaved and non-autoclaved concrete (air hardening or steaming). The qualities of such concretes differ significantly, since autoclave treatment changes the mineralogical composition of concrete, which greatly affects the profitability of energy-related technological processes associated with the environment and ultimately forms the basis of environmental planning and management.
\end{abstract}

\section{Introduction}

In 1919, it was proposed for the first time to use metal powder for gas generation in the production of cellular concrete, and now zinc, magnesium, and aluminum powder are used for this purpose (the latter is the most widely used). A chemical reaction occurs between aluminum and calcium hydroxide; as a result, large amounts of gas (hydrogen) and heat are emitted. The reaction binds water, which accelerates the thickening and setting of the concrete mixture. Aluminum powder forms gas pores (cells) with a uniform structure, which is extremely important for increasing the quality of products and increasing their durability in the operation of buildings. Sand, binders, and water are evenly mixed with aluminum powder. The prepared solution, still not containing gas, is poured into molds. After that, a chemical reaction occurs with the evolution of hydrogen. The gas bubbles formed during this process swell the solution, which is distributed around the bubbles and

\footnotetext{
${ }^{*}$ Corresponding author: r.kazarian@mail.ru
} 
forms a uniform cellular structure of the concrete. One of the options for producing foam concrete involves adding of freshly prepared foam or a foaming agent to the mixture with further mixing.

\section{Materials and methods}

One of the first patents for obtaining foam concrete was issued to Bayer in 1925. Later, Christian and Nilsson (Sweden) proposed a method for making foam concrete when cement and soap solutions were poured into molds for thickening and hardening after intensive joint mixing (obtaining a porous mixture). A method with a foaming agent in the form of alkali-soluble condensation products of phenol-aldehyde was invented in Germany (the foaming agent is mixed with the mixture, or foam is prepared separately, further mixing it with the mixture). High-molecular organic substances (saponins, proteins, soap, enelatina, sulfonates, etc.) are used for the preparation of foam. Many different foaming agents have been proposed, which were more or less successfully tested in industrial conditions. Following foaming agents have found wide application: rosin size, resinous, aluminosulfonic foaming agents and hydrolyzed blood. The rapid development of the production of new highly effective surfactants allowed the creation of various highly effective foaming agents. The number of patents for the production of foam concrete is much higher than for aerated concrete [1-3].

At the end of the 20th century, worldwide, the annual production of cellular concrete products was in the range of 43-45 million $\mathrm{m}^{3}$. The largest number of companies have an annual production of 160-200 thousand $\mathrm{m}^{3}$, and the largest enterprise, built in 1987 in Hungary under the license of "Hebel", reached a productivity of cellular concrete over 560 thousand $\mathrm{m}^{3}$ per year. A number of CIS countries, Poland, China, the Czech Republic, Slovakia, Denmark, Japan, and others have their own domestic developments and technologies, which they use along with licensed ones. Technologies differ in the methods of preparation (grinding), molding of a cellular concrete mixture, and cutting of blocks into products of specified sizes [2-3].

According to the cutting technology, a complete set of products for a cellular concrete houses for low-rise construction is produced. The accuracy of the manufactured products is due to the different technical solutions of the cutting equipment (length and diameter of the cutting string) and depends on the structural and mechanical properties and dimensions of the cellular concrete block being cut.

\section{Results}

In the technologies of the "Ytong" and "Masa-Henke" companies, before cutting into products of a given size, the raw cellular concrete block is cut to size and shape at $90^{\circ}$, and in the "Wehrhahn" technology - onto a pallet specially placed under a side surface, on which the block without mold is fed under the cutting machines, then into the autoclave and into the warehouse of finished products.

In the technologies of the companies "Hebel", "Durox", "Aerok", and "Silbet", the mold are removed from the block, it is transferred with a special grab from the plane of the mold pallet to the cutting machine table, cut, then placed on the bars and fed to the autoclave and the warehouse of finished products.

In the "Siporex" technology, a block without mold (the sides of the mold are lifted upwards) is cut into its slotted tray, after which the sides of the mold are lowered into their original position, and the mold with the block is fed into the autoclave. Heat and moisture 
treatment is carried out in dead-end and pass-through autoclaves with a diameter of 2.4-2.8 $\mathrm{m}$ and a length of up to $50 \mathrm{~m}$ at a pressure not lower than $1.0 \mathrm{MPa}$.

In the technologies of listed above and other foreign companies, finished products are sent to the consumer in packed form (in shrink film or in packages that are tied with metal or synthetic tapes). As a rule, products are produced with a density of $400-700 \mathrm{~kg} / \mathrm{m}^{3}$ and concrete strength under compression, consequently, not less than 2.0-5.0 MPa.

When delivered to the consumer, the moisture content of cellular concrete products is about $20 \%$ by volume or $30-35 \%$ by weight. During the construction and operation of buildings, the moisture content of cellular concrete in enclosing structures is reduced to equilibrium operational one and is $2-3 \%$ by volume with an average concrete density of 600 $\mathrm{kg} / \mathrm{m}^{3}$.

Reinforced products are produced with length up to $7.2 \mathrm{~m}$, width up to $0.75 \mathrm{~m}$, and thickness up to $0.375 \mathrm{~m}$. The step of products in length is $5-25 \mathrm{~mm}$ and in thickness is 25 $100 \mathrm{~mm}$, and the width of products is usually equal to the height of the molded block.

The length of reinforced products depends on their thickness and design loads. The maximum length of products is usually equal to the length of the moldable or cut block. Unreinforced products (small blocks and partition walls) are made of any size, and the block length or the width of the partitions is equal to the height of the block. The sizes of small blocks comply with the requirements of STB 1117-98 "Wall blocks of cellular concrete", GOST 25485, DIN 4165, etc.

In the 50 s of the last century, reinforced products made of structurally heat-insulating concrete had a density of $800-1000 \mathrm{~kg} / \mathrm{m}^{3}$, and by 1996 , for mass production, it dropped to $650-750 \mathrm{~kg} / \mathrm{m}^{3}$.

In 1965, at the Lyubertsy Combine of Building Materials and Structures (Moscow Region), a cellular concrete workshop was commissioned, using a new vibration technology developed in the USSR. Due to the use of mixtures with a low amount of mixing water, this technology has provided:

- reduction of pre-autoclave aging of freshly molded raw material to 1-2 hours;

- decrease in humidity of products;

- improved strength, frost resistance, and durability of the products with the same density of cellular concrete;

- increased manufacture of finished products from the volume unit of the autoclave and the production area of the workshop.

For the manufacture of products from cellular concrete, binders, silica components, and gas forming agents are used:

binders:

- Portland cement;

- calcium quicklime;

- granulated blast furnace slag;

- ash from burning oil shale and some types of brown coal;

silica components:

- quartz sand or silica-containing waste from the mining and mineral processing industry;

- ash from burning brown and black coal;

gas forming agents:

- aluminum powder or paste, which is used with the addition of surfactants;

- plasticizing agents regulating gas formation and thickening.

The raw materials used for the manufacture of products from cellular concrete must meet certain requirements. The suitability of raw materials and properties of cellular concrete is determined on the basis of technological tests. The scope of testing is specified in each case. 


\section{Binders:}

a) Portland cement (GOST 10178). Type M400-500, without active mineral additives. The content of tricalcium silicate is not less than $50 \%$, tricalcium alumina is not more than $6 \%$. The specific surface of the cement must be at least $3000 \mathrm{~cm}^{2} / \mathrm{g}$. Start of setting - no later than 2 hours, the end - no later than 4 hours after mixing;

b) calcium quicklime (GOST 9179; SN 277-80). The content of active $\mathrm{CaO}$ and $\mathrm{MgO}$ is not less than $70 \%$, including $\mathrm{MgO}$ is not more than $5 \%$. The amount of burnout is not more than $2 \%$. Slaking rate $-5-15 \mathrm{~min}$;

c) granulated domain slag (basic and neutral) (GOST 3476). The content of manganese oxide is not more than $1.5 \%$, sulfide sulfur is not more than $0.1 \%$. The modulus of activity is not less than 0.4 , the modulus of basicity is not less than 0.9 ;

d) ash from burning oil shale and some types of brown coal. $\mathrm{CaO}$ content is not less than $30 \%$ (including free $\mathrm{CaO}$ not less than $15 \%$ ). $\mathrm{SiO} 2$ from 20 to $30 \%$. $\mathrm{CO} 3$ is not more than $6 \%$. K2O + Na2O - not more than 3.5\%. The specific surface of the ash is $3000-3500$ $\mathrm{cm}^{2} / \mathrm{g}$.

Silica components:

a) quartz sand (GOST 8736; SN 277-80). The content of quartz (free SiO2) is not less than 70\%; alkalis (expressed as $\mathrm{Na} 2 \mathrm{O}$ ) - not more than $2.7 \%$; sulfur and sulfate compounds (expressed as $\mathrm{SO} 3$ ) - not more than $0.5 \%$; mica is not more than $0.5 \%$; dust, silty, and clay particles - no more than $5 \%$. The recommended maximum grain size of sand is no more than $3 \mathrm{~mm}$ with a grain content of $0-1 \mathrm{~mm}$ in the range of $60-80 \%$;

b) acid ash from burning brown and black coal, caught in electrostatic precipitators (OST 21-60; SN 277-80). The quartz content of $\mathrm{SiO} 2$ is not less than $45 \%$; $\mathrm{CaO}$ is not more than 10\%; sulfur and sulfate compounds (expressed as SO3) - not more than $2 \%$; residues of unburned fuel: for hard coal - not more than 7\%; for brown coal - not more than $5 \%$. The specific surface is not less than $2500 \mathrm{~cm} 2 / \mathrm{g}$.

Gas forming agents: Aluminum powder or paste based on it (GOST 5494-71).

Water for production: (GOST 23732; STB 1114).

For the preparation of cellular concrete, you can use water suitable for the preparation of conventional concrete. The maximum content in $\mathrm{mg} / \mathrm{l}$ : soluble salts - 10,000; SO4 ions 2700; C1-1 ions - 3500; suspended solids - 300 .

Chemical additives: These surfactants are prescribed depending on the type of binder and clarify empirically. To regulate the process of structure formation, the increase in plastic strength and accelerate the hardening of the cellular concrete mixture, as well as its plasticization, the following are used:

- two-water gypsum;

- soda ash;

- triethanolamine;

- trisodium phosphate;

- liquid glass;

- sulfanol;

- superplasticizers and other substances.

Reinforcing steel for the manufacture of cages: For the manufacture of reinforcement (cages and grids), reinforcing steel is used that meets the requirements of GOST 10922. The control tests of the strength of steel are carried out in accordance with GOST 12004. As an anticorrosion coating for the reinforcement, following are applied:

- cold cement-bitumen mastic;

- cement-polystyrene mastic;

- latex-cement mastic;

- latex-mineral mineral mastic;

- inhibited shale-bitumen-cement mastic; 
- metal silicate mastic;

- anticorrosion coating for steel.

Anticorrosion coatings must meet the following requirements:

- resistance to impact of at least $10 \mathrm{kgf} / \mathrm{cm}^{2}$ according to GOST 4765;

- elasticity no more than $20 \mathrm{~mm}$ in accordance with GOST 10086;

- thickness of the coating of the reinforcement after drying is $0.4-0.7 \mathrm{~mm}$;

- solid coating without cracks and through pores;

- the coating must be able to withstand transportation, piling and laying of reinforcement into the mold.

Lubricants: For lubrication of molds, materials of the following composition are used (in the ratio by weight):

- petrolatum-kerosene mixture 1: 2.5;

- grease or avtol with kerosene 1: 1;

- a mixture of oil and engine oil 1:3;

- various liquid or film separating coatings that prevent the adhesion of raw cellular concrete to steel.

\section{Discussion}

In 1991, in the USSR, 5.7 million $\mathrm{m}^{3}$ of structures and products made of cellular concrete were released, including reinforced (panels of walls and coatings) - 1.6 million $\mathrm{m}^{3}$, unreinforced (large and small blocks) - 2.6 million $\mathrm{m}^{3}$, and heat insulating slabs - 1.5 million $\mathrm{m}^{3}$. It was decided to bring the volume of production of cellular concrete products to 40-45 million $\mathrm{m}^{3}$ in 1995 . Unfortunately, we have to talk about the experience of the USSR as a foreign experience: we live in another country. Therefore, it is difficult to separate the successes and shortcomings of the USSR in the production of cellular concrete products from the successes and shortcomings of the Russian Federation in this field. A related reference data for the Russian Federation is provided in the following text [4-6].

The above-mentioned program for increasing the production of cellular concrete products initially envisaged increasing capacities for producing only small cellular concrete blocks on the set of equipment of the "Universal-60" (SMS-301) line with a capacity of 80 thousand $\mathrm{m}^{3}$ products per year (standard project 409-021-4887). In the future, when designing (tying up a standard project) new plants, it was planned to equip this line with a third autoclave (3.6 $\mathrm{m}$ in diameter) and switch to a three-shift operation in order to bring capacity of this line up to 120 thousand $\mathrm{m}^{3}$ per year. The subsequent increase in line capacity up to $160-240$ thousand $\mathrm{m}^{3}$ of products per year was planned by installing semiconveyors, the fourth autoclave, increasing the height of the moldable block to $0.9 \mathrm{~m}$, expanding the mixing station, and developing an automated conveyor line "Conrex 90/240" with a capacity of 240 thousand $\mathrm{m}^{3}$ per year [7-9].

For comprehensive testing of the production technology of small cellular concrete blocks using autoclaves with a diameter of $2 \mathrm{~m}$, molding blocks with a height of $1.2 \mathrm{~m}$ and cutting them into products of given sizes on pallets of molds without transferring the block (as it is carried out on the "Universal-60" line), four plants with a capacity of 160 thousand $\mathrm{m}^{3}$ per year were planned to build in Belarus (Bobruisk, Lyuban, Orsha, Petrikov), two plants in Ukraine and Kazakhstan, and seven plants with a capacity of 40-400 thousand $\mathrm{m}^{3}$ per year in the Russian Federation.

The mentioned program was based on the use of domestic experimental and newly created equipment for the production of small cellular concrete blocks, using impact cutting and vibration cutting technologies. For the production of reinforced products (exterior and interior wall panels, slabs and ceilings) and small cellular concrete blocks, equipment was purchased from "Ytong" company with the right of its reproduction. In 1989-1995, in the 
USSR, it was planned to build 400-450 factories for the production of industrial products from cellular concrete with a capacity of 50-200 thousand $\mathrm{m}^{3}$ per year on the basis of domestic and replicated equipment manufactured by "Ytong" company, including manufacturing 50 sets of technological lines of new generation with a capacity of 100-200 thousand $\mathrm{m}^{3}$ per year in 1990 [8-10].

It was planned to organize at cement factories the production of binders with low water demand and technological equipment for the production of non-autoclaved wall blocks from cellular concrete based on binders with low water demand with a capacity of 50 thousand $\mathrm{m}^{3}$ per year, including 40 production lines in 1989-1990.

To coordinate the plans listed for 1989-1995, the program "Creation of highly efficient types of cellular concrete with specified properties based on new binders, development of a new generation of building structures, technologies, equipment, and creation of highly automated technological equipment" was developed.

The program not only provided for the creation of highly automated technological equipment, but, starting from 1995, implied the development of a pilot industrial highly automated line for the production of cellular concrete products with a density of 500-550 $\mathrm{kg} / \mathrm{m}^{3}$ and $600-650 \mathrm{~kg} / \mathrm{m}^{3}$ (compressive strength of $4-5 \mathrm{MPa}$ and $6-7 \mathrm{MPa}$, respectively).

After the collapse of the USSR, in which the only head of all work on the development of the production of cellular concrete products was the USSR State Committee for Construction (Gosstroy), nearly all programs across the CIS were stopped, and State Committee for Construction was liquidated [11].

In a number of cities of the CIS and Baltic countries, buildings of up to 25 floors have been built from cellular concrete (Yekaterinburg, St. Petersburg, Saratov, Tallinn, etc.).

At CIS plants, as a rule, the release of the entire range of reinforced products is ensured by the use of a significant number of individual molds of different sizes. The number of panel sizes for the construction of a single series of a residential building or a public building is up to 100 pieces, and the weight of an outfit is $750-800$ tons of metal. The fill factor of the autoclave in the manufacture of reinforced products in individual molds is $0.25-0.30$, and by the cutting technology is $0.40-0.45$. Steam consumption in the production of concrete with density of $500-600 \mathrm{~kg} / \mathrm{m}^{3}$ in individual molds is $250-280 \mathrm{~kg} / \mathrm{m}^{3}$, and by the cutting technology is $165-190 \mathrm{~kg} / \mathrm{m}^{3}$.

The production-line technology for the production of cellular reinforced concrete products in individual molds was borrowed from the experience of manufacturing reinforced concrete products at the very beginning of the development of the production of autoclaved materials and is still used at the plants of the CIS countries. From a volume of 1.6 million $\mathrm{m}^{3}$ of production of reinforced products in the CIS countries, only 130 thousand $\mathrm{m}^{3}$ are produced per year by cutting technology (Avtovskiy DSK, Belgorod-Dnestrovsky ZYABI, PO "Vangazhi”, Pavlodarsky KZhBI-4).

The main disadvantage of the manufacture of reinforced products in individual molds is the dependence of the quality of the manufacture of products on the quality of the outfit. High deformability and low strength of raw cellular concrete require the use of rigid outfit to prevent the formation of technological cracks at the stages of pre-autoclave curing and hydrothermal treatment. This increases the material intensity of production, reduces the output of finished products from the autoclave. The outfit, being under constant mechanical, cyclic, and thermal influence, demands frequent preventive and major repairs. Otherwise, the quality of products is constantly decreasing over time. The disadvantage of the considered technology is the need to completely replace the molds when switching to a new type of product. The horizontal position of the molds during the preparatory operations, the molding of the products and the cutting or rolling of the "end piece" require considerable production space, additional volumes of manual labor, and a significant increase in the number of means of mechanization and transportation. 
These disadvantages are absent in the cutting technology of manufacturing products, when a block with dimensions of $6.0 \times(1.2-1.5) \times(0.6-0.9) \mathrm{m}$ or $6,0 \times 0,9 \times 0,9 \mathrm{~m}$ is formed in the mold with reinforcement cages installed and fixed in it. Then the block is cut with special machines for products of specified sizes, which allows getting products different in length, thickness and width with profiles, grooves, chamfers, and keys in the same molds. After autoclaving, additional machining can be performed: further calibration of products, cutting the "groove-crest" and "pockets" for gripping during masonry, etc.

The technical and economic analysis of the production of reinforced cellular concrete products using cutting technology shows that in comparison with manufacturing in individual molds, it is possible to:

reduce:

- specific quantity of metal of molds per $1 \mathrm{~m}^{3}$ of finished products by 3 times;

- specific heat consumption for autoclave treatment by $18 \%$;

- specific capital investments for the production of products by $16 \%$;

increase productivity of:

- autoclave compartment by 1.5 times;

- molding span by 4.7 times;

- one worker of main production by $21 \%$;

- labor at the whole enterprise by $14 \%$.

Unlike in a number of foreign countries, where the finishing of cellular concrete products is carried out at the construction site, in the CIS countries, as a rule, the finishing of reinforced wall panels is carried out at the factory. In the case of a mass typical state construction, this approach met the requirements of the time. However, the quality and the range of raw materials used for protective and decorative coatings and the quality of the coatings themselves do not allow ensuring the necessary appearance and durability of building facades.

In recent years, cellular concrete has been intensively used again in Russia and the Republic of Belarus. Currently, in Russia, one plant in the village of Sertolovo in the Leningrad Region and two plants in the city of Lipetsk produce cellular concrete products according to the technology of the "Hebel" company. In Novosibirsk, the plant "Sibit", JSC "Glavnovosibirsk", and in the city of Vodino, Samara region, JSC "Combine for the production of products from cellular concrete" and "Cottage" mastered the production of cellular concrete products according to the technology of the "Y tong" company. Plants with a capacity of 120 thousand $\mathrm{m}^{3} /$ year produce wall blocks with a density of $400-600 \mathrm{~kg} / \mathrm{m}^{3}$ and reinforced products with a density of $700 \mathrm{~kg} / \mathrm{m}^{3}$ (slabs, ceilings, and lintels). In the city of Naberezhnye Chelny, OJSC "Cellular Concrete Plant" developed, manufactured and mastered a production line for the production of cellular concrete products, which is similar to the cutting technology of the "Ytong" or "Masa-Henke" companies, but without tilting the block.

According to the molding technology, the block is molded in a vertical outfit $(6.0 \times 0.626 \times 1.3 \mathrm{~m})$ consisting of stationary opening sides and a replaceable pallet. After the raw cellular concrete gained the required plastic strength, the sides of the mold are opened, and the pallet with a vertically standing block is moved with a special crosshead suspended on the crane under cutting machines for cutting the "end piece", side vertical longitudinal cutting of the block, horizontal longitudinal cutting, and vertical cross cutting.

CJSC "Corporation of Building Materials" (Moscow), OJSC "Volgocemmash" (Tolyatti), and VNIISTROM Institute named after P.P. Budnikov (Kraskovo village, Moscow region) developed the crane-free conveyor line of the "Vibroblock" system, with a production capacity of 30-120 thousand $\mathrm{m}^{3} /$ year. Cellular concrete blocks with a size of $3000 \times 1300 \times 1270 \mathrm{~mm}$ are made by vibration cutting technology (vibration mixing of the components of the cellular concrete mixture, vibration molding of blocks and their cutting 
into products of specified sizes). The main sample of the line with an annual productivity of 100 thousand $\mathrm{m}^{3}$ (VKA-100) was manufactured, assembled and mastered by OJSC "Volgocemmash".

CJSC "Silbetindustriya" (Moscow) develops technological equipment for the construction of new and modernization of existing cellular concrete plants using domestic impact technology and various options for cutting a block into products of specified size.

In the Republic of Belarus, back in 1997, a plant for the production of cellular concrete products according to the technology of the "Hebel" company was put into commercial operation by OJSC "Zabudova". The design capacity of the plant is 200 thousand $\mathrm{m}^{3}$ of reinforced and unreinforced products per year. In 2003, the plant produced 307 thousand $\mathrm{m}^{3}$ of cellular concrete products in cooperation with the "Masa-Henke" company, and is working to increase the capacity to 370 thousand $\mathrm{m}^{3}$ of products per year. Of the total production, $50 \%$ is concrete with a density of $400 \mathrm{~kg} / \mathrm{m}^{3}$.

The "Hebel" company designed in the project the requirements for the raw materials, especially for cement and lime (calcium oxide content, hydration kinetics, grinding fineness, setting time, mineralogical composition, etc.), that exceed the requirements of GOST and STB, i.e. such cement and lime do not produced in the Republic of Belarus and the CIS countries. For example, the raw materials of the "Kolyadichi" deposit, used for the production of cement at OJSC "Krasnoselskcement", and the existing technology for the production of clinker with short rotary kilns do not allow obtaining clinker with a saturation factor above 0.9 . The construction industry enterprises do not produce lime with a calcium oxide content of more than $80 \%$, and the lime hydration kinetics does not meet the requirements of DIN 1060.

Specialists of the engineering and technical center of OJSC "Zabudova" and UPP "Plant of Building Structures" developed a series of cellular concrete mixture formulations for concrete densities of $350-700 \mathrm{~kg} / \mathrm{m}^{3}$, based on the raw material base of the Republic of Belarus. More than 30 mixture formulations have been introduced into production, allowing producing cellular concrete products and structures of different density and strength. The plant produces a complete set of materials for a house from a cellular concrete according to the standards of the Republic of Belarus (STB): unreinforced blocks (STB 1117-98), slabs and ceilings (STB 1034-96), trough and arc lintels (STB 1332-2002), wall panels (STB 1185-99), elements of stairs (STB 1330-2002). The products received certificates of conformity of the Republic of Belarus, Russia, Lithuania, Latvia, etc. The production of cellular concrete is certified according to the International Quality System ISO 9001. In 2002, the plant was awarded the Prize of the Government of the Republic of Belarus for achievements in the field of quality [12-16].

Residential, public, and social-domestic buildings are being built from cellular concrete produced by OJSC "Zabudova" and UPP "Plant of Building Structures". For example, in Minsk, two microdistricts "Bolshaya Slepyanka" and the "Izvestia" Newspaper" avenue are built up with cellular concrete cottages. In Moscow, there are experimental microdistricts "Kurkino", "Mitino", "Eden", etc. Cellular concrete is widely used in enclosing structures of multi-storey buildings. In Minsk, Moscow, and in other regions of Russia, as well as in the Baltic countries, a number of tall buildings have been built, including a complex of residential buildings on Mosfilmovskaya Street and the building of the British Embassy in Moscow. The study and critical analysis of the world and domestic experience in the production of cellular autoclaved concrete, as well as the use of impact technology, allows modernizing cellular concrete plants and increasing production volumes.

The Republic of Belarus uses modern sets of technological equipment (primarily mixing, cutting and packaging), combining domestic impact technology and foreign cutting technologies of leading German companies "Masa-Henke", "Verhan", "Hebel”, etc. 


\section{Conclusions}

The technological process of manufacturing cellular concrete products includes (Fig. 1):

- reception and preparation of raw materials;

- preparation of a cellular concrete mixture;

- cutting of blocks;

- autoclave treatment and demoulding;

- large assembly for the production of large-sized products.

Binding materials can be delivered to the plant by rail, road, or other means of transport. Their storage is provided in silos with a capacity of $60 \div 120 \mathrm{t}$. The number of silos is chosen depending on the capacity of the plant, distance from suppliers of materials, and type of transport. Transportation of binding materials at the plant is carried out by pneumatic transport. The materials used as the silica component are unloaded into the receiving bunker; they are fed by a conveyor belt to the screen, where fine contamination is separated from the oversize fraction, which is sent to grinding for the preparation of sludge and limesand binder.

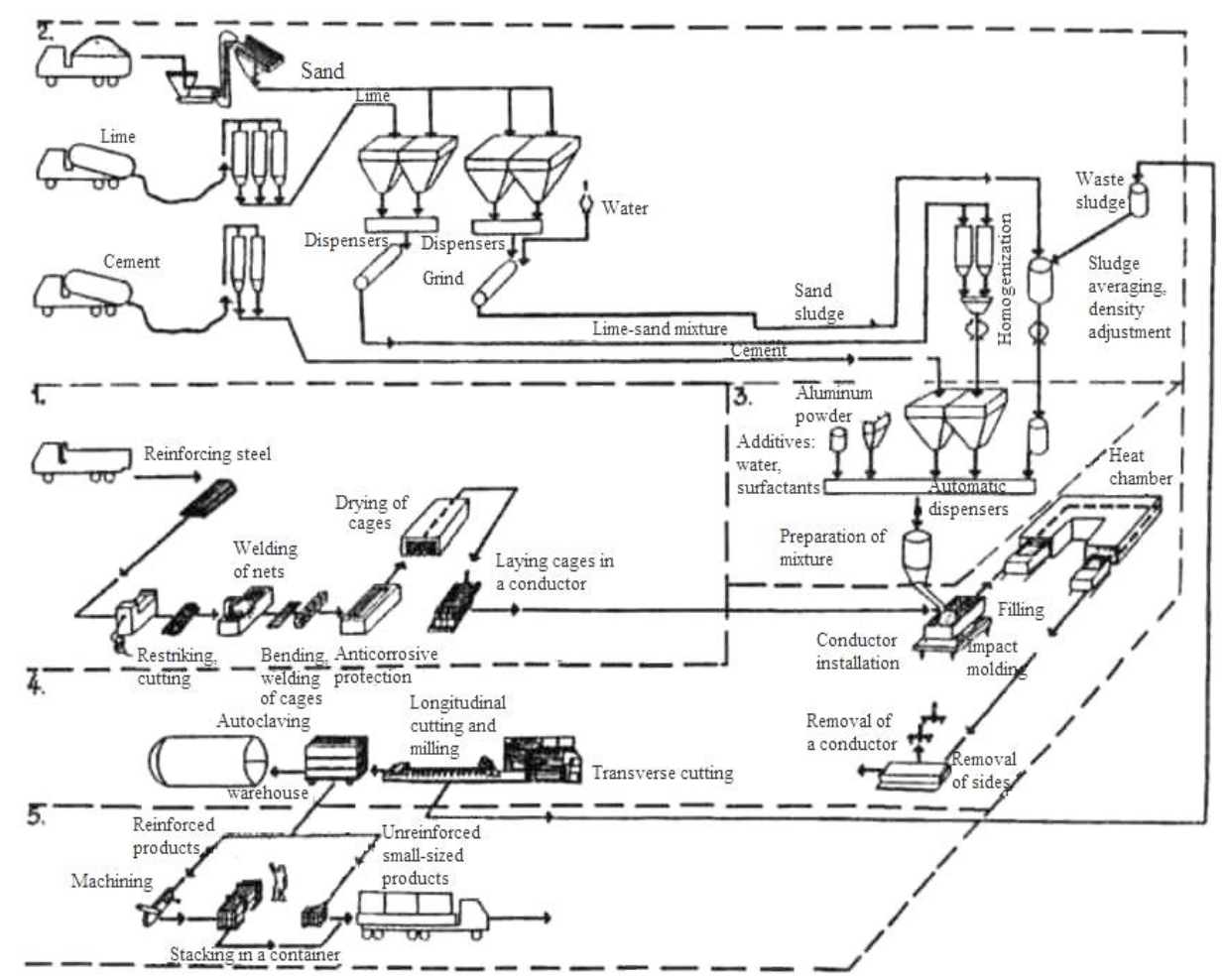

Fig. 1. Plant for the production of products from cellular concrete: 1 - manufacture of reinforcement cages; 2 - reception and handling of raw materials; 3 - preparation of a cellular concrete mixture; 4 forming, cutting and autoclaving of blocks; 5 - control, packaging, warehousing, and transportation of finished products.

Among the components of the cellular concrete mixture, which are subject to preliminary preparation (grinding):

- mixed binder (lime-cement, lime-slag, slag-alkali, lime-sand);

- ash binder;

- silica component (ground quartz sand or sour ash from thermal power plants). 
Using natural sand (silica component), quicklime and cement as raw materials, cellular concrete products are produced using impact technology (Fig. 2).

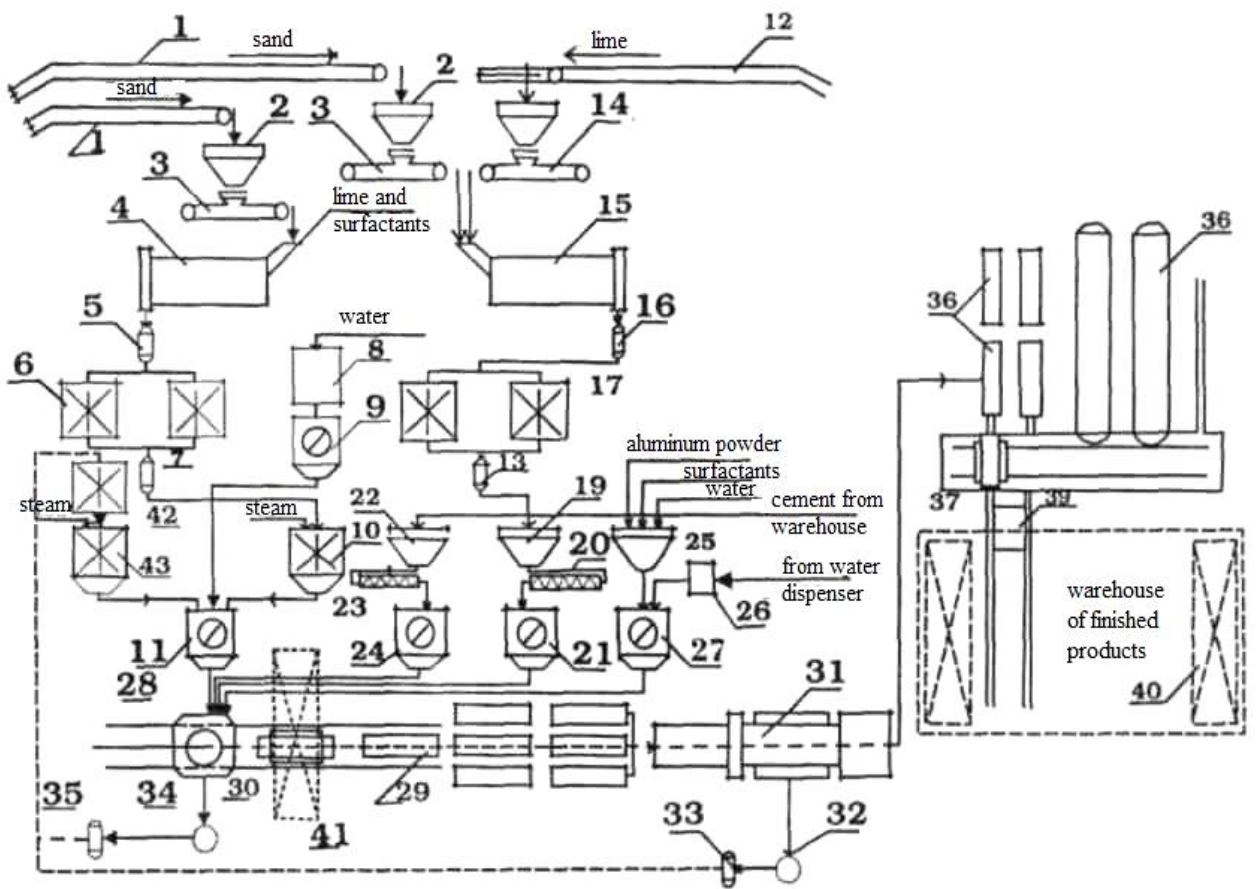

Fig. 2. Production of cellular concrete products using impact technology: 1 - belt conveyor; 2 - sand bunker; 3 - belt feeder; 4 - wet grinding mill; 5 - sludge air-feed unit; 6 - mechanically mixed sludge tank; 7 - sludge air-feed unit; 8 - tank for water dispensing; 9 - water dispenser; 10 - sand sludge storage tank with mechanical agitation; 11 - sludge and waste dispenser; 12 - belt conveyor; 13 - lime hopper; 14 - belt feeder; 15 - dry grinding mill; 16 - lime-sand mixture air-feed unit; 17 homogenizers; 18 - lime-sand mixture air-feed unit; 19 - lime-sand mixture bunker; 20 - conveyor for screw feed of binder in the dispenser; 21 - binder dispenser; 22 - cement hopper: 23 - conveyor for screw feed of cement into the dispenser; 24 - cement dispenser; 25 - aluminum suspension preparation unit; 26 - water tank for washing the aluminum suspension dispenser; 27 - aluminum suspension dispenser; 28 - vibration gas concrete mixer; 29 - molds with blocks of raw cellular concrete; 30 - molding post with shock pads; 31 - complex of cutting units; 32 - waste receiving tank with a stirrer; 33 and 35 - chamber pumps; 34 - tank for supplying washing mixtures from vibration gas concrete mixers; 36 - molds cleared and greased for filling of mixes; 37 - power transmission bridge; 38 - autoclaves; 39 - autoclave trolley; 40 - two-hook travelling bridge crane in the warehouse of finished products; 41 - bridge crane at the molding station; 42 - storage tank for waste sludge with mechanical mixing: 43 - waste sludge tank with mechanical mixing.

\section{References}

1. V.O. Chulkov, Production and use of construction materials, products and systems (SvR-ARGUS, Moscow, 2011)

2. I.A. Rybiev, Construction materials science (Visshy school, Moscow, 2002)

3. I.Kh. Nanazashvili, I.F. Bunkin, V.I. Nanazashvili, Construction materials and product (Adelant, Moscow, 2005)

4. A.A. Ivliyev, A.A. Kalgin, O.M. Skok, Finishing construction works, Textbook (ProfObrIzdat, Moscow, 2001) 
5. B.A. Lyovin, R.R. Kazaryan, V.O. Chulkov, Infographics of anthropotechnical management, Infographic modeling in the mental activity philosophy (Moscow, 2016)

6. V.O. Chulkov, O.N. Kuzina, Control for investment-construction and housing-andmunicipal complexes, International collection of research papers (MGAKHiS, Moscow, 2010)

7. V.O. Chulkov, O.N. Kuzina, Current problems of housing and municipal services development in cities and population centers, International collection of research papers of the 9th International research and practice conference (Saint Sophia-Kavala, Moscow, 2010)

8. A.A. Volkov, V.O. Chulkov, G.O. Chulkov, R.R. Kazaryan, O.N. Kyzina, Advanced Materials Research 1065-1069, 2401-2404 (2015) doi: 10.4028/www.scientific.net/AMR.1065-1069.2401

9. A.A. Volkov, V.O. Chulkov, G.O. Chulkov, R.R. Kazaryan, O.N. Kyzina, Advanced Materials Research 1065-1069, 2405-2408 (2015) doi: 10.4028/www.scientific.net/AMR.1065-1069.2405

10. A.A. Volkov, V.O. Chulkov, G.O. Chulkov, R.R. Kazaryan, O.N. Kyzina, Advanced Materials Research 1065-1069, 2405-2408 (2015) doi: 10.4028/www.scientific.net/AMR.1065-1069.2409

11. C. Gini, Statistika (Corrado Gini, Milano, 2010)

12. A.S. Gorshkov, N.I. Vatin, Magazine of Civil Engineering 40, 5-19 (2013) doi:10.5862/MCE.40.1

13. A.S. Gorshkov, P.P. Rymkevich, N.I. Vatin, Magazine of Civil Engineering 52 (2014) doi:10.5862/MCE.52.5

14. A.S. Gorshkov, P.P. Rymkevich, Magazine of Civil Engineering 60, 68-82 (2015) doi:10.5862/MCE.60.8

15. S.V. Korniyenko, N.I. Vatin, A.S. Gorshkov, Magazine of Civil Engineering 64, 10-25 (2016) doi:10.5862/MCE.64.2

16. A.S. Gorshkov, N.I. Vatin, P.P. Rymkevich, O.O. Kydrevich, Magazine of Civil Engineering 78, 65-75 (2018) doi:10.18720/MCE.78.5 